\title{
Pre-sowing Seed Treatments with Botanicals, Magnetic and Electric on Seedling Characters of Pearl Millet (Pennisetum glaucum L.)
}

\author{
Patil Tejas Ramesh* and Prashant Kumar Rai \\ Department of Genetics and Plant Breeding, Sam Higginbottom University of Agriculture, \\ Technology and Sciences, Prayagraj, U.P., India \\ *Corresponding author
}

\section{A B S T R A C T}

\section{Keywords}

Curry leaf extract, Neem leaf extract, Coconut water, Magnetic field, Electric field, Seed priming, Pearl millet seed

Article Info

Accepted: 12 December 2020 Available Online: 10 January 2021
The effect on given experiment was carried out to investigate the "Pre-sowing seed treatments with Botanicals, Magnetic and Electric on seedling characters of Pearl millet (Pennisetum glaucum L.)" in the post graduate experiment laboratory of seed science at Department of Genetics and Plant Breeding, SHUATS, Prayagraj (UP). The different seed priming techniques on germination and seedling characters of pearl millet an experiment was conducted in 2019-2020, the experiment based on complete randomized design (CRD). Seed were primed with three different method ( $\mathrm{T}_{0^{-}}$control (unprimed), $\mathrm{T}_{1^{-}}$curry leaf extract(3\%) for 8 hours, $\mathrm{T}_{2}$ - neem leaf extract(3\%) for 8 hours, $\mathrm{T}_{3}$ - coconut water(3\%) for 8 hours, $\mathrm{T}_{4}$ - magnetic field(100 gauss) for 30 minutes, $\mathrm{T}_{5^{-}}$magnetic field(150 gauss) for 30 minutes, $\mathrm{T}_{6}$ - magnetic field(200 gauss) for 30 minutes, $\mathrm{T}_{7^{-}}$electric field $(100 \mathrm{~mA})$ for 1 minute, $T_{8}$ - electric field $(150 \mathrm{~mA})$ for 1 minute, $T_{9}$ - electric field $(200 \mathrm{~mA})$ for 1 minute). The results revealed that, all the priming treatments showed significance difference with control and the highest germination percent, speed of germination, germination energy $(\%)$, root length $(\mathrm{cm})$, shoot length $(\mathrm{cm})$, seedling length $(\mathrm{cm})$, seedling fresh weight $(\mathrm{gm})$, seedling dry weight $(\mathrm{gm})$, vigour index I, vigour index II, test weight $(\mathrm{gm})$, moisture content $(\%)$ and protein content $(\%)$ were observes in coconut water@3\% compare to control. Among the treatments coconut water @ 3\% was found to be the best priming treatment. The study helps to improve the quality of seeds with the help of seed priming treatments which are cost effective and eco-friendly sources.

\section{Introduction}

Pearl millet (Pennisetum glaucum L.) $(2 n=14)$ is a native of Sahel zone of West Africa, which was introduced to eastern Africa and Indian sub-continent. The common name of pearl millet worldwide includes Pearl, Bulrush, Cat tail or spiked millet (Gill, 1991) that belongs to botanical family
Poaceae. While, in India it is called as bajra, which is a low prices food grain crop. It is the sixth most important crop after wheat, rice, maize, barley and sorghum in terms of annual global production to the tune of 10.7 percent (Chaudhari et al., 2018).

Pearl millet is the only cereal that reliably provides both grain and fodder on poor, sandy 
soils under hot, dry conditions. It is remarkable that it produces nourishment from the poorest soils in the driest regions in the hottest climate. In the drier regions of Africa and Asia, the crop is a staple food grain.

In more favoured areas, however, pearl millet grain is fed to bullocks, milch animals and poultry. In India, pearl millet is grown on more than 7.48 million ha with a production of 9.21 million tonnes and $1231 \mathrm{kgha}^{-1}$ productivity (IIMR,2018).

The nutritive value of pearl millet grains includes fairly high percentage of carbohydrate $(69.4 \%), 12.1$ percent protein, 4.3 to 5.0 percent fat and 2 to 7 percent mineral matter. It is also rich in vitamins, thiamine and riboflavin contents and imparts substantial energy to the body with easy digestibility (Pal et al., 1996).

Pearl millet can be grown under areas of high temperature, low and uncertain rainfall and shallow or sandy soil with poor fertility and low water holding capacity. These are the major constraints to increasing pearl millet productivity. In order to increase the productivity pre-sowing seed treatment is one of the important objectives in pearl millet.

Pre-sowing seed treatments with water, plant growth regulators, agro-chemicals, fungicides etc. also have been reported to increase the seed quality in several crop species. Improved seed priming techniques are being used in many parts of the world to reduce the germination time, synchronize germination, improve germination rate and increase plant stand (Khan, 1992 and Lee and Kim, 2000).

Seed priming is a widely used technique to enhance seed performance, notably with respect to rate and uniformity of germination thereby enabling better crop establishment (Heydecker, 1978 and Bradford, 1986).

\section{Materials and Methods}

Seeds of Pearl millet of variety Parbhani Sampada, obtained from VNMAU, Parbhani (MH), India. Present investigation was carried out at Post-Graduate laboratory of Seed Science and Technology at the Department of Genetics and Plant Breeding, Naini Agricultural Institute, Sam Higginbottom University of Agriculture, Technology and Sciences, Prayagraj (UP) during 2018-2020.

\section{Procedure of preparation of leaf extracts}

The powdered of separately shade dried leaves using electric grinder. Take three grams Powder and dissolved in $100 \mathrm{ml}$ of distilled water to make 3 percent leaf extract solution. These solutions were kept at room temperature for 48 hours. After 48 hours the leaf extracts were filtered by two layer of muslin cloth to remove unwanted material and leaf debris. Seeds were soaked independently in leaf extracts at room temperature for eight hours. After soaking seeds were air dried (Prabha et al., 2016).

\section{Procedure for preparation of Coconut water}

The tender coconut water is directly used as seed treatment $3 \mathrm{ml}$ of coconut water were added separately in $100 \mathrm{ml}$ of water to get 3 percent solutions which were used for seed treatment. Pearl millet seeds were soaked in coconut water for $8 \mathrm{hrs}$ and then seeds were air dried overnight (Amarnath et al., 2015).

\section{Procedure for magnetic field}

To treat the seeds electromagnetic field generator "OMEGA EMU-10" with variable horizontal magnetic strength with a gap of $5 \mathrm{~cm}$ between pole pieces was used. Magnetic field flows through the cylinders when we input the power supply. A DC power supply 
$230 \mathrm{AC}$ (0-4 Amp) (10\% AC 50HZ) with continuously variable output current was used for the electromagnet. A digital gauss meter OMEGA DGM-20 (230V AC $+10 \%$ at $50 \mathrm{HZ})$ was used to monitor the field strength produced in the pole gap of magnetic field generator. The metallic probe made of indium arsenide crystal and encapsulated to a nonmagnetic sheet is used. This could measure in steps of the magnetic field (Dimitrios et al., 2013)

\section{Procedure for electric field}

To expose the seeds to electric field, an electric field generator was fabricated by using metallic conductor. A battery of $24 \mathrm{~V}$ DC was used as the power source for the electric field treatment topearl millet seeds. A battery is connected with ammeter to measure electric current and ammeter is connected with rheostat to adjust the current supply.

A metallic conductor was connected between rheostat and battery. The seed are placed on a metallic conductor and electric current of $24 \mathrm{~V}$ DC was passed at required intensities for one minute (Dalavaiet al., 2018).

For seedling characters, the germination test was conducted using four replications of 100 seeds in each replication. The between paper method used as per procedure described by ISTA.

Speed of germination were determined by Maguire (1962),seedling dry weight and vigour index I and II were determined by Baki and Anderson (1973),lowry method was followed for protein analysis.

\section{Details of methodology}

\section{Germination percentage}

Germination $(\%)=\frac{\text { Number of germinated seeds }}{\text { Total number of seed sown }} \times 100$

\section{Speed of germination}

Speed of germination $=\frac{\mathrm{G} 1}{\mathrm{D} 1}+\frac{\mathrm{G} 2}{\mathrm{D} 2}+\frac{\mathrm{G} 3}{\mathrm{D} 3} \cdots \cdots \cdots+\frac{\mathrm{Gn}}{\mathrm{Dn}}$

Where, $G_{1}, G_{2}, G_{3}, \ldots . G_{n}$ are the number of seeds germinated on $D_{1}, D_{2}, D_{3}, \ldots \ldots D_{n}$ day.

Germination energy (\%)

Germination energy $(\%)=\frac{\text { Germinated seeds after } 4 \text { day }}{\text { Total number of seeds sown }}$ X 100

Measurement of shoot, root and total seedling length $(\mathrm{cm})$

The length of root, shoot and total seedling was measured in centimetre upto one decimal.

\section{Fresh weight of seedling (gm)}

10 seedlings from each replication were taken randomly. The fresh weight of seedlings was weighted on electronic balance.

\section{Dry weight of seedling (gm)}

10 seedlings were dried in hot air oven at $103^{\circ} \mathrm{C}$ temperature for 1 hours. The dried seedlings were weighted on electronic balance.

Seed vigour index-I= Germination (\%) $\mathrm{x}$ Total seedling length

Seed Vigour index-II = germination $(\%) \mathrm{X}$ seedling dry weight

\section{Test weight (gm)}

For recording test weight, 1000 seeds are taken and weighted on electrical balance.

\section{Moisture content (\%)}

Moisture content of seed is calculated by hot air oven method, in this method, 5gm sample 
taken in the sample pan and noted as $W 1$. Then samples are kept in oven at $130^{\circ} \mathrm{C}$ for 1 hr. after withdrawing the sample pans from the oven then weight and noted as $W 2$ and moisture percentage is calculated by formula,

Moisture percentage $=\frac{\frac{W 1-W 2}{W 1}}{W 100}$

\section{Protein analysis by lowry method}

\section{Results and Discussion}

The effect of pre-sowing seed treatments on seeds of pearl millet. The data reveals that the significantly highest seed germination percentage was found in $\mathrm{T}_{3}-$ coconut water (91.50\%) followed by $\mathrm{T}_{2}-(90.25 \%)$. while lowest seed germination percentage as compared to $\mathrm{T}_{0}-(77.50 \%)$. Has been found, highest speed of germination was found in $\mathrm{T}_{3}$ - coconut water (26.38) followed by $\mathrm{T}_{2}-$ (26.17). while lowest speed of germination as compared to $\mathrm{T}_{0}-(18.86)$, also significantly highest germination energy was found in $\mathrm{T}_{3}-$ coconut water $(65 \%)$ followed by $\mathrm{T}_{2}-(63 \%)$. while lowest germination energy as compared to $\mathrm{T}_{0}-(47 \%)$.
A performance of a seed treatments, the significantly highest root length was found in $\mathrm{T}_{3}$ - coconut water $(18.47 \mathrm{~cm})$ followed by $\mathrm{T}_{2}$ - $(17.60 \mathrm{~cm})$ while lowest root length as compared to $\mathrm{T}_{0}-(11.80 \mathrm{~cm})$. Has been found, significantly highest shoot length was found in $\mathrm{T}_{3}-$ coconut water $(9.32 \mathrm{~cm})$ followed by $\mathrm{T}_{2}-(8.72 \mathrm{~cm})$. while lowest shoot length as compared to $\mathrm{T}_{0}-(5.85 \mathrm{~cm})$, also significantly highest seedling length was found in $\mathrm{T}_{3}-$ coconut water $(27.80 \mathrm{~cm})$ followed by $\mathrm{T}_{2}-$ $(26.32 \mathrm{~cm})$ while lowest seedling length as compared to $\mathrm{T}_{0}-(17.65 \mathrm{~cm})$.

The effect of pre-sowing seed treatment on seedling fresh weight of pearl millet, the data reveals that the significantly highest seedling fresh weight was found in $\mathrm{T}_{3}$ - coconut water $(0.89 \mathrm{gm})$ followed by $\mathrm{T}_{2}-(0.87 \mathrm{gm})$ while lowest seedling fresh weight as compared to $\mathrm{T}_{0}-(0.66 \mathrm{gm})$. Has been found significantly highest seedling dry weight was found in $\mathrm{T}_{3}-$ coconut water $(0.18 \mathrm{gm})$ followed by $\mathrm{T}_{1}-$ (0.18 gm) while lowest seedling dry weight as compared to $\mathrm{T}_{0}-(0.15 \mathrm{gm})$.

Table.1 Treatment details

\begin{tabular}{|c|c|c|c|}
\hline Symbols & Treatments & $\begin{array}{c}\text { Concentration/ } \\
\text { Intensity }\end{array}$ & $\begin{array}{c}\text { Duration of } \\
\text { exposure }\end{array}$ \\
\hline $\mathrm{T}_{0}$ & Control & $3 \%$ & 8 hours \\
\hline $\mathrm{T}_{1}$ & Curry leaf extract & $3 \%$ & 8 hours \\
\hline $\mathrm{T}_{2}$ & Neem leaf extract & $3 \%$ & 8 hours \\
\hline $\mathrm{T}_{3}$ & Coconut water & 100 gauss & 30 minutes \\
\hline $\mathrm{T}_{4}$ & Magnetic field & 150 gauss & 30 minutes \\
\hline $\mathrm{T}_{5}$ & Magnetic field & 200 gauss & 30 minutes \\
\hline $\mathrm{T}_{6}$ & Magnetic field & $100 \mathrm{~mA}$ & 1 minute \\
\hline $\mathrm{T}_{7}$ & Electric treatment & $150 \mathrm{~mA}$ & 1 minute \\
\hline $\mathrm{T}_{8}$ & Electric treatment & $200 \mathrm{~mA}$ & 1 minute \\
\hline $\mathrm{T}_{9}$ & Electric treatment & & \\
\hline
\end{tabular}


Table.2.a Mean performance for seedling characters of pearl millet

\begin{tabular}{|c|c|c|c|c|c|c|c|}
\hline S.No. & Treatments & $\begin{array}{c}\text { Germination } \\
\text { percentage }\end{array}$ & $\begin{array}{c}\text { Speed of } \\
\text { germination }\end{array}$ & $\begin{array}{c}\text { Germination } \\
\text { energy }(\%)\end{array}$ & Root length $(\mathrm{cm})$ & $\begin{array}{l}\text { Shoot length } \\
(\mathrm{cm})\end{array}$ & $\begin{array}{l}\text { Seedling length } \\
(\mathrm{cm})\end{array}$ \\
\hline 1 & $\mathrm{~T}_{0}$ & 77.50 & 18.86 & 47 & 11.8 & 5.85 & 17.65 \\
\hline 2 & $\mathrm{~T}_{1}$ & 89.50 & 25.01 & 60 & 16.72 & 8.37 & 25.10 \\
\hline 3 & $\mathrm{~T}_{2}$ & 90.25 & 26.17 & 63 & 17.60 & 8.72 & 26.32 \\
\hline 4 & $\mathrm{~T}_{3}$ & 91.50 & 26.38 & 65 & 18.47 & 9.32 & 27.80 \\
\hline 5 & $\mathrm{~T}_{4}$ & 86.00 & 22.61 & 49 & 14.55 & 8.05 & 22.60 \\
\hline 6 & $\mathrm{~T}_{5}$ & 88.25 & 23.56 & 53 & 15.85 & 8.20 & 24.00 \\
\hline 7 & $\mathrm{~T}_{6}$ & 82.00 & 21.77 & 52 & 12.60 & 6.52 & 19.12 \\
\hline 8 & $\mathrm{~T}_{7}$ & 83.75 & 22.55 & 53 & 13.87 & 7.35 & 21.22 \\
\hline 9 & $\mathrm{~T}_{8}$ & 86.50 & 25.38 & 56 & 15.57 & 7.92 & 23.50 \\
\hline 10 & $\mathrm{~T}_{9}$ & 80.50 & 20.88 & 50 & 12.60 & 6.55 & 19.15 \\
\hline \multicolumn{2}{|c|}{ Grand Mean } & 85.57 & 23.11 & 54.52 & 14.96 & 7.68 & 22.65 \\
\hline \multicolumn{2}{|c|}{ C.D. $(1 \%)$} & 4.56 & 1.46 & 4.00 & 1.21 & 0.50 & 1.36 \\
\hline \multicolumn{2}{|c|}{ S.E. } & 1.65 & 0.53 & 1.45 & 0.44 & 0.18 & 0.49 \\
\hline \multicolumn{2}{|c|}{ C.V. } & 2.74 & 3.25 & 3.77 & 4.17 & 3.40 & 3.09 \\
\hline
\end{tabular}


Table.2.b Mean performance for seedling characters of pearl millet

\begin{tabular}{|c|c|c|c|c|c|c|c|c|}
\hline S.No. & Treatments & $\begin{array}{c}\text { Fresh wt. of } \\
\text { seedling (gm) }\end{array}$ & $\begin{array}{c}\text { Dry wt. of } \\
\text { seedling (gm) }\end{array}$ & $\begin{array}{l}\text { Seed vigour } \\
\text { index I }\end{array}$ & $\begin{array}{l}\text { Seed vigour } \\
\text { index II }\end{array}$ & $\begin{array}{c}\text { Test weight } \\
\text { (gm) }\end{array}$ & $\begin{array}{c}\text { Moisture } \\
\text { content }(\%)\end{array}$ & $\begin{array}{l}\text { Protein content } \\
(\%)\end{array}$ \\
\hline 1 & $\mathrm{~T}_{0}$ & 0.66 & 0.15 & 1367.15 & 11.62 & 9.29 & 10.38 & 8.20 \\
\hline 2 & $\mathrm{~T}_{1}$ & 0.84 & 0.18 & 2248.30 & 16.11 & 10.53 & 12.52 & 8.45 \\
\hline 3 & $\mathrm{~T}_{2}$ & 0.87 & 0.17 & 2376.18 & 15.34 & 10.40 & 12.60 & 8.38 \\
\hline 4 & $\mathrm{~T}_{3}$ & 0.89 & 0.18 & 2543.40 & 16.47 & 10.73 & 12.79 & 8.90 \\
\hline 5 & $\mathrm{~T}_{4}$ & 0.72 & 0.17 & 1941.23 & 14.62 & 9.57 & 11.37 & 8.43 \\
\hline 6 & $\mathrm{~T}_{5}$ & 0.74 & 0.16 & 2122.30 & 14.12 & 9.47 & 11.58 & 8.56 \\
\hline 7 & $\mathrm{~T}_{6}$ & 0.73 & 0.16 & 1568.52 & 13.12 & 9.67 & 11.67 & 8.67 \\
\hline 8 & $\mathrm{~T}_{7}$ & 0.70 & 0.16 & 1778.12 & 13.40 & 9.53 & 11.69 & 8.26 \\
\hline 9 & $\mathrm{~T}_{8}$ & 0.74 & 0.16 & 2032.75 & 13.84 & 9.41 & 11.51 & 8.24 \\
\hline 10 & $\mathrm{~T}_{9}$ & 0.72 & 0.15 & 1542.35 & 12.07 & 9.52 & 11.42 & 8.32 \\
\hline \multicolumn{2}{|c|}{ Grand Mean } & 0.76 & 0.16 & 1951.06 & 14.40 & 9.81 & 11.75 & 8.44 \\
\hline \multicolumn{2}{|c|}{ C.D. $(1 \%)$} & 0.03 & 0.01 & 145.19 & 1.74 & 0.41 & 0.36 & 0.14 \\
\hline \multicolumn{2}{|c|}{ S.E. } & 0.01 & 0.07 & 52.79 & 0.63 & 0.15 & 0.13 & 0.05 \\
\hline \multicolumn{2}{|c|}{ C.V. } & 2.55 & 6.00 & 3.82 & 6.24 & 2.20 & 1.58 & 0.90 \\
\hline
\end{tabular}


Astatically significant variation in seed vigour index I of Pearl millet. It is evident from the table that maximum increase in seed vigour index $\mathrm{I}$ occurs by $\mathrm{T}_{3}-$ coconut water (2543.40) followed by $\mathrm{T}_{2}-$ (2376.18). while lowest seed vigour index I as compared to $\mathrm{T}_{0}$ - (1367.15), also seed vigour index II occurs by $\mathrm{T}_{3}-$ coconut water (16.47) followed by $\mathrm{T}_{2}$ - (16.11). while lowest seed vigour index II as compared to $\mathrm{T}_{0}-(11.62)$.

The significantly highest test weight was found in $\mathrm{T}_{3}-$ coconut water $(10.73 \mathrm{gm})$ followed by $\mathrm{T}_{1}-(10.53 \mathrm{gm})$. while lowest test weight as compared to $\mathrm{T}_{0}-(9.29 \mathrm{gm})$, also significantly highest moisture content was found in $\mathrm{T}_{3}-$ coconut water $(12.79 \%)$ followed by $\mathrm{T}_{2}-(12.60 \%)$. while lowest moisture content as compared to $\mathrm{T}_{0}$ $(10.38 \%)$.

The effect of pre-sowing seed treatment on protein content of pearl millet. The data reveals that the significantly highest protein content was found in $\mathrm{T}_{3}-$ coconut water $(8.90 \%)$ followed by $\mathrm{T}_{6}-(8.67 \%)$. while lowest protein content as compared to $\mathrm{T}_{0}-$ $(8.20 \%)$. Seed priming stimulates many of the metabolic processes (physiological and chemical) involved with the early phases of germination. Moreover, it has been noted that seedlings from primed seeds emerge faster, grow more vigorously, and perform better in adverse saline conditions (Cramer, 2002).

Seed vigour index length parameter depends on germination percentage, shoot length and root length. Result of the present study suggested that seed priming was effective tools for seed invigoration in sorghum. Similar findings were reported by (Amarnath et al., 2015)

It is concluded that the present investigation of the different priming treatments showed significant effect on seedling parameters of pearl millet. Priming with coconut water at $3 \%$ for $8 \mathrm{hrs}$. show the suitable results for seedling parameters viz., seed germination percentage $(91.50 \%)$, speed of germination (26.38), germination energy $(65 \%)$, root length $(18.47 \mathrm{~cm})$, shoot length $(9.32 \mathrm{~cm})$, seedling length $(27.8 \mathrm{~cm})$, seedling fresh weight $(0.89 \mathrm{gm})$, seedling dry weight (0.18gm), seed vigour index I (2543.40), seed vigour index II (16.47), test weight (10.73 gm), moisture content (12.79\%) and protein content $(8.90 \%)$ statically compared with other treatments.

\section{Acknowledgement}

The authors are thankful to the Dr. Suresh B.G. Professor and HoD and all the members of the Department of Genetics and Plant Breeding, Naini Agricultural Institute, Sam Higginbottom University of Agriculture, Technology and Sciences, Prayagraj, U.P., for providing all necessary facilities and support.

\section{References}

Abdul-Baki, A.A. and Anderson, J.D. (1973). Vigour determination in soybean seeds by multiple criteria. Crop science, 13: 630-633.

Amarnath, B. H., Arvind Kumar, Niranjana Chaurasia, Vivekanad V. and Ashish Kumar Singh (2015).Effect of priming with botanicals and animal waste on germination and seedling vigour in sorghum (Sorghum bicolorL.) seeds.Advances in Applied Science Research,6(10):73-77.

IIMR, (2018).Selected state-wise area, production and productivity of bajra in India (2016-2017 and 2017-2018) http:/www.millets.res.in.

Bradford, K. J. (1986).Manipulation of seed water relationship via osmotic priming to improve germination under stress conditions. Horticulture Science, 21: 
1102-1112.

Chaudhari, R. P., Patel, P. M., Patel, B. M., Kumar, U., Darji, S. S., and Patel, S. J., (2018).Performance of summer pearl millet (PennisetumglaucumL.) hybrids under North Gujarat conditions. International Journal of Current Microbiology and Applied Science, 7(1): 637-644.

Cramer, G.R. (2002). Herbal treatment interactions under salinity stress. Salinity: Environment-plants-molecules, 10: 205-227.

Dalavai Srikanth, Prashant Kumar Rai, Saritha Khandka and G.B.N. Jyothi (2018).Influence of Magnetic and Electric Field on Germination Attributes of Chilli (Capsicum annum L.) Seeds. International Journal of Pure and Applied Bioscience, 6(3): 496-501.

Dimitrios J. Bilalis, Nikolaos Katsenios, Aspasia Efthimiadou, AnestisKarkanis, Ebrahim M. Khah, TertyllianosMitsis (2013).Magnetic field pre-sowing treatment as an organic friendly technique to promote plant growth and chemical elements accumulation in early stages of cotton. Australian Journal of Crop Science, 7(1):46-50.
Gill, K. S., (1991). Pearl millet and its improvement. Indian Council of Agricultural Research, New Delhi.

Heydecker, W. (1978). Primed seeds for better crop establishment Span, 21: 1214.

ISTA 2010. International rules for seed testing.Seed Science and Technology, 27: 1-334.

Khan, AA. (1992).Per plant physiological seed conditioning. Annual Review of HorticultureScience, 13: 131-183.

Lee, S.S. and Kim, JH (2000).Total sugar, aamylase activity and germination after priming of normal and aged rice seeds.Korean Journal ofCrop Science, 44(2): 108-111.

Pal, M., Deka, J. and Raj, R. K., (1996).Fundamentals of cereals crop production. Tata McGraw Hill Publishing Co. Ltd., New Delhi, India.

Prabha Deepti, Swati Negi, Poonam Kumari, Yogesh Kumar Negi, J.S. Chauhan (2016).Effect of Seed Priming with Some Plant Leaf Extract on Seedling Growth Characteristics and Root Rot Disease in Tomato. International Journal of Agriculture System,4: 46-51.

\section{How to cite this article:}

Patil Tejas Ramesh and Prashant Kumar Rai. 2021. Pre-sowing Seed Treatments with Botanicals, Magnetic and Electric on Seedling Characters of Pearl Millet (Pennisetum glaucum L.). Int.J.Curr.Microbiol.App.Sci. 10(01): 1472-1479. doi: https://doi.org/10.20546/ijcmas.2021.1001.175 